\title{
Nitrogen Requirements of Pinot noir Based on Growth Parameters, Must Composition, and Fermentation Behavior
}

\author{
R. Paul Schreiner, ${ }^{1 *}$ James Osborne, ${ }^{2}$ and Patricia A. Skinkis ${ }^{3}$
}

\begin{abstract}
A study to reassess the nitrogen $(\mathrm{N})$ requirements for Pinot noir was carried out using a pot-in-pot vineyard where $\mathrm{N}$ inputs were carefully controlled. Pinot noir grafted on 101-14 rootstock was exposed to five levels of $\mathrm{N}$ supply beginning in their fourth growing season, and vine productivity, berry chemistry, and must fermentation dynamics were studied over three years. $\mathrm{N}$ supply altered the $\mathrm{N}$ status of vines in accordance with expectations. Varying $\mathrm{N}$ had a greater impact on vegetative growth parameters than upon reproductive responses. For example, at veraison, leaf area of vines exposed to the three lowest rates of $\mathrm{N}$ was reduced in all years, but yield was only reduced at the lowest $\mathrm{N}$ rate in the first year and at the two lowest $\mathrm{N}$ rates in subsequent years. Fruitfulness and fruit set were reduced slightly by low $\mathrm{N}$, while flower number of inflorescences was unaffected. Effects on berry maturity indices at harvest were generally small, but effects on must yeast assimilable nitrogen (YAN) concentrations were large. YAN was reduced from $\sim 200 \mathrm{mg} \mathrm{N} / \mathrm{L}$ in the Control to as low as $25 \mathrm{mg} \mathrm{N} / \mathrm{L}$ at the lowest $\mathrm{N}$ rate after three years. Treatments with lower YAN required more time to complete alcoholic fermentation, particularly those with YAN below $100 \mathrm{mg}$ N/L. However, all musts fermented to dryness. Reducing vegetative growth of Pinot noir can be achieved prior to reducing yield by reducing $\mathrm{N}$ status when vines are cropped at levels typical for premium wine production in the region. YAN levels as low as $100 \mathrm{mg} \mathrm{N} / \mathrm{L}$ may be a better production target for wineries to achieve minimum fermentation requirements of Pinot noir.
\end{abstract}

Key words: leaf nitrogen, pruning weight, Vitis vinifera, YAN, yield

Nitrogen $(\mathrm{N})$ influences the productivity and fruit composition of winegrapes and is often the most important nutrient to manage in vineyards, since it has a large impact on vine productivity (Roubelakis-Angelakis and Kliewer 1992, Bell and Henschke 2005). Excessive N supply results in increased vegetative growth (vigor), often at the expense of reproductive growth and/or fruit ripening (Wheeler and Pickering 2003, Delgado et al. 2004). High N supply resulting in increased vegetative growth can also lead to undesirable effects in berries due to increased shading of clusters that decreases color development (Keller et al. 1999, Hilbert et al. 2003) and an increased incidence of Botrytis infection (Conradie and Saay-

'USDA-ARS-Horticultural Crops Research Unit, 3420 NW Orchard Avenue, Corvallis, OR 97330; ${ }^{2}$ Department of Food Science, 100 Wiegand Hall; and ${ }^{3}$ Department of Horticulture, 4017 ALS Building, Oregon State University, Corvallis, OR 97331.

*Corresponding author (Paul.Schreiner@ars.usda.gov; tel: 541-738-4084; fax: 541-738-4025)

Acknowledgments: The authors thank Matthew Scott, Suean Ott, Keira Newell, Alejandra Navarrete, and Alison Reeve for technical assistance and Duarte Nursery Inc. (Hughson, CA) for providing certified grapevines. This work was funded, in part, by the Oregon Wine Board, the Oregon Wine Research Institute, and USDA-ARS CRIS 2072-21000-048-00D. Mention of trade names or commercial products in this publication is solely for the purpose of providing specific information and does not imply recommendation or endorsement by the U.S. Department of Agriculture.

Supplemental data is freely available with the online version of this article at www.ajevonline.org.

Manuscript submitted May 2017, revised Aug 2017, accepted Sept 2017

Copyright $\odot 2018$ by the American Society for Enology and Viticulture. All rights reserved.

doi: 10.5344/ajev.2017.17043 man 1989). Too little $\mathrm{N}$ can reduce fruit yield and quality by reducing fruit set or berry growth directly, or by reducing vegetative growth too severely to ripen the fruit (Kliewer et al. 1991, Bell and Robson 1999). Low N concentrations in berries leading to low yeast assimilable nitrogen (YAN) levels can reduce fermentation rates and presumably wine quality in many grapegrowing regions (Bell and Henschke 2005). In commercial production, it is generally accepted that grape must YAN values of $140 \mathrm{mg} \mathrm{N} / \mathrm{L}$ are required to obtain alcoholic fermentations that complete to dryness and reduce the risk of yeast-produced hydrogen sulfide (Jiranek et al. 1995, Bell and Henschke 2005, Martinez-Moreno et al. 2012). While vine $\mathrm{N}$ status is routinely measured by commercial vineyards using leaf blades or petioles collected at bloom or veraison (see Schreiner and Scagel 2017 for a brief history on leaf and petiole testing), specific tissue $\mathrm{N}$ status benchmarks required to meet specific production or fruit composition goals are not well defined (Schreiner et al. 2013, 2014).

Recent work using a pot-in-pot system to investigate $\mathrm{N}$ requirements for own-rooted Pinot noir showed that lowering $\mathrm{N}$ status reduced amino acid contribution to YAN the most, but increased some berry secondary metabolites including anthocyanins, phenolic acids, and condensed tannins (Schreiner et al. 2013, 2014). Independent of changes in berry size, an increase in condensed tannins and phenolic acids was shown to occur, while anthocyanins and other phenols were related to $\mathrm{N}$-induced changes in berry size. Others also reported increased polyphenolics or tannins in red wine cultivars as $\mathrm{N}$ status declines (Keller et al. 1999, Hilbert et al. 2003, Delgado et al. 2004, Pérez-Álvarez et al. 2013), indicating that N status must be balanced, not only between vegetative and reproductive growth, but also between primary (mainly amino-N) and 
secondary metabolites that are known to alter red wine quality. In general, moderate to low levels of $\mathrm{N}$ appear to be beneficial for improving fruit quality in red cultivars (Bell and Robson 1999, Treeby et al. 2000, Pérez-Álvarez et al. 2013).

Critical leaf blade values of $25 \mathrm{~g} \mathrm{~N} / \mathrm{kg}$ DW (dry weight) at bloom and $18 \mathrm{~g} \mathrm{~N} / \mathrm{kg}$ DW at veraison were proposed for ownrooted Pinot noir in order to maintain yields typical for commercial producers in the Willamette Valley of western Oregon and achieve must YAN values of $140 \mathrm{mg} \mathrm{N} / \mathrm{L}$ (Schreiner et al. 2013). These $\mathrm{N}$ status targets were in general agreement or slightly higher than critical leaf blade $\mathrm{N}$ values proposed elsewhere (Conradie 2001, Robinson 2005, Linsenmeier et al. 2008). However, since tissue $\mathrm{N}$ concentrations that equate to yield or must YAN targets can vary among grape cultivars and rootstocks (Christensen et al. 1994, Conradie 2001), tissue test guidelines should be defined for both cultivars and rootstocks used within a given production region.

The goal of this study was to evaluate how N supply affects both vegetative and reproductive parameters in grafted Pinot noir grapevines and how fruit chemistry and fermentation behavior are altered by $\mathrm{N}$ status. Based on these responses, a second goal was to test whether the proposed leaf blade and petiole $\mathrm{N}$ standards obtained previously (Schreiner et al. 2013) would apply also to grafted Pinot noir vines. Pinot noir was grown in a pot-in-pot vineyard where varying levels of $\mathrm{N}$ were precisely controlled so that vine responses to $\mathrm{N}$ could be carefully examined. Fruit was thinned on all vines, retaining a single cluster per shoot to achieve yields similar to current industry standards for production of premium Pinot noir wines in western Oregon.

\section{Materials and Methods}

Pot-in-pot vineyard system and experimental design. The data used for this study was obtained over three consecutive growing seasons (2012 to 2014) in a microplot (pot-in-pot) vineyard (Schreiner et al. 2013) on Pinot noir grapevines that received five different levels of $\mathrm{N}$ at the beginning of their fourth growing season (Schreiner and Scagel 2017). Briefly, grafted 'Pinot noir' grapevines (certified Vitis vinifera L. Pommard clone FPS 91 on 101-14 rootstock, Duarte Nursery Inc.) were grown in $60 \mathrm{~L}$ pot-in-pot (Grip Lip 6900T, Nursery Supplies Inc.) microplots installed at the Oregon State University Lewis Brown Research Farm, Corvallis, OR $\left(44.553^{\circ} \mathrm{N}\right.$; $123.216^{\circ} \mathrm{W}$ ). Pots were filled with $50 \mathrm{~L}$ of a mix including 3:1 coarse sand (pre-stress sand mix, Knife River Inc.): Jory soil series (fine, mixed, active, mesic Xeric Palehumult collected from the Oregon State University Woodhall Research Vineyard). Dormant one-year-old vines were planted in the microplots in May 2009, spaced at $1.0 \mathrm{~m} \times 3.2 \mathrm{~m}$, and trained on a single Guyot system using vertical shoot positioning. Vines were pruned to two buds in February 2010 and two shoots were grown to the top wire until mid-July. At this time, the largest shoot was cut $0.5 \mathrm{~m}$ from ground level and retained as the trunk and the smaller shoot was pruned off. Two laterals that developed just below the new trunk in 2010 were allowed to grow to the top wire in 2010. One of these laterals served as the fruiting cane for 2011, and the other was pruned to two buds to serve as the renewal spur. From 2011 to 2014, vines were pruned to 12-bud canes plus a two-bud renewal spur, and later thinned to 10 shoots per cane and a single renewal spur after threat of frost had passed each spring. Main shoots were trimmed (hedged) about two weeks after fruit set at a height of $2.2 \mathrm{~m}$ from ground level. All vines received complete nutrient solution (half-strength Hoagland's solution; Hoagland and Arnon 1950) for the first three years after planting (2009 to 2011), delivered via fertigation three times per week from budbreak to veraison and approximately two times per week from veraison to harvest. In 2011, clusters were thinned to obtain five clusters per vine (a small crop) about three weeks after fruit set by retaining a single cluster on alternate shoots. Vines were irrigated during the growing season as needed based on volumetric soil water content $\left(\theta_{\mathrm{v}}\right)$ and vine water status, using a similar approach as described (Schreiner et al. 2013). The $\theta_{\mathrm{v}}$ was measured by time domain reflectometry (TDR; Soil Moisture Equipment Corp.) using $45 \mathrm{~cm}$ steel waveguides (rods) installed vertically in the pots halfway between the vine trunk and the pot edge. One set of waveguides was installed in each plot replicate in the center vine in each plot.

Treatments with varying $\mathrm{N}$ levels were applied to vines from 2012 to 2014. The concentration of $\mathrm{N}$ was supplied at four lower rates $(75,50,30$, or $15 \%$ of the Control rate) along with the Control (100\%), where the total concentration of $\mathrm{N}$ in the Control during fertigation was $7.5 \mathrm{mM}$ (equivalent to halfstrength Hoagland's solution) (Hoagland and Arnon 1950). All other nutrients ( $\mathrm{P}, \mathrm{K}, \mathrm{Ca}, \mathrm{Mg}, \mathrm{S}, \mathrm{Fe}, \mathrm{Mn}, \mathrm{B}, \mathrm{Zn}, \mathrm{Cu}$, and $\mathrm{Mo}$ ) were held constant, with macronutrients except $\mathrm{K}$ supplied at the half-strength Hoagland's rate, and all micronutrients at full strength Hoagland's rate. K was supplied at a higher rate of $4.5 \mathrm{mM}$ total $\mathrm{K}$ (instead of $3 \mathrm{mM}$ ) based on the low $\mathrm{K}$ status of vines from a previous trial using similar microplots with $100 \%$ sand as a growing medium (Schreiner et al. 2013). Treatments were the Control $(100 \% \mathrm{~N})$ and four treatments with $75,50,30$, or $15 \% \mathrm{~N}$. Each treatment was replicated four times in a randomized complete block design, and each replicate plot consisted of five continuous vines. Border rows of Pinot noir were also planted on both sides of the microplot vineyard and managed to obtain similar canopy size as the experimental vines. Vines were fertigated at varying $\mathrm{N}$ rates about three times per week from budbreak to veraison and approximately two times per week from veraison to harvest by supplying four $\mathrm{L}$ of the respective nutrient solution per fertigation event per microplot (see Supplemental Table 1 for actual dates and total $\mathrm{N}$ applied to the Control vines). To ensure that fertilizer salts did not accumulate during the summer, vines were irrigated for a 2-hr period (16 L) on a single day at the beginning of July, August, and September in each year. The potential accumulation of salts was monitored by measuring the soil electrical conductivity (EC) using a soil probe at multiple depths (Model number 2265FSTP, Spectrum Technologies Inc.). The EC values were always below $1.2 \mathrm{mS} / \mathrm{cm}$.

Clusters were thinned approximately two weeks after fruit set in 2012 to 2014 to one cluster per shoot, including the renewal shoot (spur), by retaining either the basal cluster (in 
most cases) or the second cluster. The second cluster was only retained if the basal cluster was unusually small, which occurred on the renewal spur shoots. Fungicides were used to manage powdery mildew (Erysiphe necator [Schw. Burr.]) and bunch rot (Botrytis cinerea L.), per standard practices in the region. Differences in fruit cluster solar exposure and vine water status resulting from differences in canopy size among different $\mathrm{N}$ treatments were minimized by applying variable levels of leaf removal and irrigation as described previously (Schreiner et al. 2013).

We minimized the differences in cluster solar exposure resulting from $\mathrm{N}$-induced canopy size differences to understand how $\mathrm{N}$ supply directly influenced berry composition without the interference of fruit shading, and because commercial producers apply leaf removal irrespective of vine $\mathrm{N}$ status and canopy leaf density. Basal leaves (three to four nodes) were first removed about two weeks after fruit set in the cluster zone on the east side of the canopy in all treatments to visually match cluster zone solar exposure. Immediately thereafter, cluster exposure was measured using an AccuPAR Model LP-80 ceptometer (Decagon) at 0900, 1100, 1300, 1500, and $1700 \mathrm{hr}$ by inserting the instrument into the cluster zone of the three individual (middle) vines per plot. The percent of photosynthetically active radiation (PAR) in the cluster zone was calculated based on readings taken in full sunlight adjacent to each plot. Based on these results, more leaves were removed in any replicates with too much shading until treatment differences were no longer significant. In 2012, solar exposure was matched across all $\mathrm{N}$ levels by applying greater leaf removal in the higher $\mathrm{N}$ treatments. In 2013 and 2014, solar exposure in the higher $\mathrm{N}$ levels $(100$ and $75 \% \mathrm{~N})$ was matched to cluster solar exposure in the $50 \% \mathrm{~N}$ treatment, as canopy growth at the two lowest $\mathrm{N}$ levels $(30$ and $15 \% \mathrm{~N}$ ) was insufficient to allow the same cluster exposure as the higher $\mathrm{N}$ treatments. Therefore, solar exposure of fruit clusters was greater in the two lowest N level vines in 2013 and 2014.

Rates of irrigation were differentially applied as needed to each treatment to minimize any daily differences in soil and vine water status due to $\mathrm{N}$ treatment. Less water was supplied to the lowest $\mathrm{N}$ treatments (especially 30 and $15 \% \mathrm{~N}$ vines) than to the Controls in order to achieve the same $\theta_{\mathrm{v}}$. In addition, irrigation was adjusted seasonally based on vine phenology using $\theta_{\mathrm{v}}$ so that vines were not limited by water prior to fruit set, but experienced moderate water stress between fruit set and veraison and slight water stress after veraison, as described previously (Schreiner et al. 2013). New targets for $\theta_{\mathrm{v}}$ were determined for this sand:soil mixture based on relationships between $\theta_{\mathrm{v}}$ and midday leaf water potential ( $\left.\Psi_{\text {Leaf }}\right)$ (pressure chamber, PMS Instrument Company) and stomatal conductance $\left(g_{s}\right)$ (Licor 6400 photosynthesis system or LiCor 1600 steady state leaf porometer, LiCor Inc.), and were explained in greater detail previously (Schreiner and Scagel 2017). Before fruit set, irrigation was applied to maintain $\theta_{\mathrm{v}}$ above $17 \%$ to ensure no water limitation. Between fruit set and veraison, irrigation was applied when $\theta_{\mathrm{v}}$ was between 10 and $13 \%$ to help control canopy growth and expose vines to moderate water stress. After veraison, irrigation was applied to maintain $\theta_{\mathrm{v}}$ between 14 and $15 \%$ to ensure only mild water stress. Irrigation was applied after $2100 \mathrm{hr}$ (PST) and rates were adjusted daily as needed based on mean $\theta_{\mathrm{v}}$ values per treatment.

Vine nutrient status. Vine leaf blades and petioles were collected to determine nutrient status at $50 \%$ bloom and at $50 \%$ veraison each year, based on the average $\%$ of clusters at this stage of development, as assessed visually for all clusters on each vine within each replicate. Ten leaves per plot were sampled and combined from count shoots at both bloom and veraison between 0900 and $1100 \mathrm{hr}$. Leaves opposite clusters were collected at bloom, and paired leaf samples comprising a leaf opposite a cluster and a recently expanded leaf were collected at veraison. Leaf blades and petioles were separated, rinsed in distilled water, dried at $65^{\circ} \mathrm{C}$ for $48 \mathrm{hr}$ (Shel Lab FX 28-2, Sheldon Manufacturing Inc.), and ground to pass through a $425-\mu \mathrm{m}$ sieve. $\mathrm{N}$ was determined via combustion analysis (Leco, Inc.). Other nutrient ( $\mathrm{P}, \mathrm{K}, \mathrm{Ca}, \mathrm{Mg}, \mathrm{S}, \mathrm{Fe}, \mathrm{Mn}$, $\mathrm{B}, \mathrm{Zn}$, and $\mathrm{Cu}$ ) concentrations were measured by inductively coupled plasma-optical emission spectrometry (ICP-OES; Perkin Elmer Optima 3000DV) after microwave digestion in $\mathrm{HNO}_{3}$ (Jones and Case 1990). Reference standard apple ( $\mathrm{Ma}$ lus domestica L.) leaves (no. 151, National Institute of Standards and Technology) were included in each set of samples to ensure instrument and digestion procedures were accurate. Leaf blade and petiole concentrations were expressed on a tissue DW basis.

Vine vegetative growth and photosynthesis. Shoot length and leaf area per vine were measured at bloom, and leaf area was measured at veraison in each year by first obtaining the primary shoot length and the length of all lateral shoots for all shoots on the middle three vines per plot. The area of leaves on main shoots and lateral shoots was then determined on 20 random shoots per treatment (100 total, ensuring that both larger and smaller shoots were included from each treatment) by comparing leaves to a series of concentric circles with known area as described (Schreiner et al. 2012). Leaf area per vine was calculated from the relationships between leaf area and shoot length for main shoots and for lateral shoots, and summed for all shoots per vine. Dormant season pruning mass (fresh weight of one-year-old canes) from the three middle vines per replicate was determined in winter by weighing the count shoots from the previous season. Leaf gas exchange was measured using a portable infrared gas analyzer system (LiCor 6400, LiCor Inc.) on a single leaf per plot. Fully exposed leaves (PAR $\left.>1800 \mu \mathrm{mol} / \mathrm{m}^{2} \mathrm{sec}\right)$ on a main shoot in the lower or middle canopy were measured at bloom and veraison, respectively. Measurements of gas exchange were made at various times during the day, but data collected within one hour of solar noon (1300 hr) are shown here.

Vine reproductive growth and yield parameters. Flowers and fruit set were determined by placing fine mesh fabric bags on two random clusters per plot prior to the onset of flowering. The bags were carefully removed after fruit set, ensuring that all flower caps were collected by inserting a small tray under each bag, and the total number of flower caps was counted. Each cluster used for this purpose was tagged to 
sample later, just prior to commercial maturity, and the final number of berries was counted to calculate fruit set. The date of fruit harvest in each year was based on a random sampling of berries from all plots (three berries per plot) when berries reached $\sim 22$ to 24 Brix. However, in 2013, high rainfall just prior to fruit maturity decreased berry soluble solids below 20 Brix, and fruit was eventually harvested at $\sim 21$ Brix. All plots were harvested on the same day each year. Fruit clusters were removed from the three middle vines per plot, counted, and weighed to determine yield and average cluster weight. A subsample of five randomly selected clusters from each plot were transported back to the lab to determine the number of berries per cluster and average berry weight.

Must chemistry and fermentation. The five-cluster subsample from each plot was juiced using a stainless steel handcrank press to obtain a yield equivalent to $625 \mathrm{~mL}$ must $/ \mathrm{kg}$ fresh weight of clusters using at least two pressings that were combined for analysis. Fruit maturity indices (soluble solids, $\mathrm{pH}$, and titratable acidity) were determined as previously described (Schreiner et al. 2013). YAN concentration in must was determined by summing free amino acid-N (FAA-N) obtained by the OPA (o-phthaldialdehyde) colorimetric assay (Dukes and Butzke 1998) and ammonium-N by an enzymatic assay (Sigma ammonia assay kit; Sigma Chemical Co.). Must YAN concentrations are expressed as $\mathrm{mg} \mathrm{N} / \mathrm{L}$. All must chemical parameters were analyzed in duplicate. The remaining fruit per plot was combined, stored overnight at $4{ }^{\circ} \mathrm{C}$, and destemmed the next day. Field replicates were processed separately, and $3 \mathrm{~kg}$ of each replicate was placed in 4-L micro-fermenters as described (Sampaio et al. 2007). Fermenters were placed in a temperature-controlled room set at $27^{\circ} \mathrm{C}$, warmed to room temperature, and inoculated with Saccharomyces cerevisiae RC212 (Lallemand) at $\sim 10^{6} \mathrm{cfu} / \mathrm{mL}$ after rehydration, according to the manufacturer's specifications. Fermentations were conducted with a submerged cap (Sampaio et al. 2007) and soluble solids were monitored daily using an Anton-Paar DMA 35N Density Meter. After all fermentations reached dryness $(<0.5 \mathrm{~g} / \mathrm{L}$ reducing sugar as measured by Clinitest, Bayer, Leverkusen), they were pressed using a modified basket press with an applied constant pressure of $0.1 \mathrm{MPa}$ for $5 \mathrm{~min}$. Fifty $\mathrm{mg} / \mathrm{L} \mathrm{SO}_{2}$ as potassium metabisulfite was added to the wines before they were cold-settled at $4^{\circ} \mathrm{C}$ for five days. Wines were then racked and $\mathrm{SO}_{2}$ was added to achieve 25 to $30 \mathrm{mg} / \mathrm{L}$ free $\mathrm{SO}_{2}$ prior to bottling in $375 \mathrm{~mL}$ screw-capped wine bottles (Stelvin, Amcor), and stored at $13^{\circ} \mathrm{C}$.

Statistical analysis. All statistics were conducted using Statistica software (version 12.7, Statsoft). Multivariate analysis of variance (MANOVA) was first conducted for groups of related variables to examine the interactive effect of year and treatment, accounting for the contribution and experimentwide error associated with closely related variables. Using the average value for each replicate plot, variables were grouped according to vegetative and reproductive vine parameters and must composition parameters, since many variables had multiple subsampling observations per plot. After showing that there was a significant year by $\mathrm{N}$ treatment interaction $(p<0.001)$ by MANOVA for each group of related variables, factorial ANOVA was used to examine how specific vine and fruit variables were altered by $\mathrm{N}$ supply and year, accounting for block effects in the model. Variance assumptions were tested using Cochran's test, and residuals were examined to ensure normality. Must FAA-N, must YAN, and the number of days to complete fermentation were log-transformed prior to ANOVA to satisfy variance assumptions. Means were compared using Tukey's post-hoc test at 95\% confidence. For simplicity, the mean and standard error of the mean are reported in all tables and figures. In addition, the data from the season prior to manipulating $\mathrm{N}$ (2011) is shown as a reference in figures, although this data was not included in the analysis. The concentration of leaf blade $\mathrm{N}$ at veraison that corresponded to a $30 \%$ decrease in numerous vine and must response variables was calculated by first converting the quantities for each response variable relative to the Control treatment $(100 \% \mathrm{~N})$ mean value within each year. This allowed comparison of different variables on the same scale. The point where a $30 \%$ decrease for each response variable had occurred was then computed from the regression line of the relative response values as a function of leaf $\mathrm{N}$ concentration at verasion.

\section{Results}

Weather differed among the three years of this study, leading to differences in vine development (Supplemental Table 1). Air temperatures were cooler in 2012 , leading to later development dates for bloom and veraison ( $\sim 2$ wks later than in 2013 and 2014) and a later harvest ( 2 to 3 wks later than in 2013 and 2014). Overall, 2014 was the warmest year, advancing budbreak and fruit harvest by $\sim 10$ days earlier than 2013, which was also a relatively warm year. High rainfall shortly before harvest in 2013 (including one day with $56 \mathrm{~mm}$ ) thoroughly wetted fruit clusters and decreased soluble solids, thus delaying harvest that year. It should be noted that the fruit soluble solids never fully recovered and fruit was harvested at lower Brix in 2013, ahead of another storm event.

Solar exposure of fruit clusters was not affected by $\mathrm{N}$ rates in 2012 (data not shown), but was greater in both the 30 and 15\% N treatments in 2013 and 2014 (Supplemental Table 2). Greater solar exposure was most evident in the lowest $\mathrm{N}$ vines $(15 \% \mathrm{~N})$, which had higher exposure than the Controls at 1300,1500 and $1700 \mathrm{hr}$, while the $30 \% \mathrm{~N}$ vines had more solar exposure at 1500 and $1700 \mathrm{hr}$ only. The 50 and $75 \% \mathrm{~N}$ vines did not differ from the $100 \% \mathrm{~N}$ vines at any time.

Soil water content was altered by $\mathrm{N}$ supply on a few individual days each year, as the irrigation adjustments to compensate for varying canopy size and water use among $\mathrm{N}$ treatments were not perfect (data not shown). However, these differences were generally small and were corrected the next day by adjusting irrigation rates. The season-long average $\theta_{\mathrm{v}}$ was not affected by $\mathrm{N}$ supply in 2012 or 2013, but $\theta_{\mathrm{v}}$ was greater in the 30 and $15 \% \mathrm{~N}$ treatment soils in 2014 than in the three higher $\mathrm{N}$ rates (Supplemental Table 3). The difference in the season-long $\theta_{v}$ was $\sim 1.0$ to $1.6 \%$ higher in the two lowest $\mathrm{N}$ treatments than in the higher $\mathrm{N}$ treatments in 2014.

As expected, year and $\mathrm{N}$ supply altered the $\mathrm{N}$ concentration in leaf blades and petioles sampled at bloom and veraison in 
accordance with rates of $\mathrm{N}$ (Table 1). Leaf blade $\mathrm{N}$ concentration at bloom was affected by year and $\mathrm{N}$ supply with no interaction between them, as 2012 was lower than either 2013 or 2014, and leaf blade $\mathrm{N}$ was progressively reduced as $\mathrm{N}$ declined. Bloom petiole $\mathrm{N}$ concentrations showed a less marked decline as $\mathrm{N}$ rate decreased. A year by $\mathrm{N}$ supply interaction was observed for bloom petiole $\mathrm{N}$ concentrations, because only the 30 and $15 \% \mathrm{~N}$ vines had less petiole $\mathrm{N}$ than the Control in 2012 and 2013, while all lower $\mathrm{N}$ rates were lower than the Control by 2014. At veraison, leaf blade $\mathrm{N}$ concentrations were altered by the interaction between year and $\mathrm{N}$ rate, since veraison leaf blade $\mathrm{N}$ was lower in the 50,30 , and $15 \% \mathrm{~N}$ vines in 2013 and 2014, but only the two lowest $\mathrm{N}$ rates differed in 2012. The main effect of $\mathrm{N}$ on both leaf blade and petiole $\mathrm{N}$ concentrations at veraison was similar, as reduced $\mathrm{N}$ supply resulted in less $\mathrm{N}$ in both tissues. Petiole $\mathrm{N}$ at veraison was not affected by the interaction between year and $\mathrm{N}$ supply. Comparing the main effects of $\mathrm{N}$ supply at bloom and veraison indicates that a greater separation among the $\mathrm{N}$ rates occurred at veraison as compared to bloom in both tissues. For example, the five $\mathrm{N}$ treatments resulted in four distinct leaf blade $\mathrm{N}$ concentration levels at bloom, but separated further into five groups at veraison, while only three petiole $\mathrm{N}$ levels were distinguished at bloom, but five groups occurred also at veraison.

$\mathrm{N}$ influenced leaf blade and petiole concentrations of other plant mineral nutrients, most prominently $\mathrm{P}$ and sulfur (S) (data not shown). Focusing on the veraison data for brevity, low $\mathrm{N}$ supply increased $\mathrm{P}$ status and reduced $\mathrm{S}$ status in vines. Leaf blade and petiole $\mathrm{P}$ concentrations were higher in the $15 \% \mathrm{~N}$ (leaf blade $\mathrm{P}=2.0 \mathrm{~g} / \mathrm{kg} \mathrm{DW}$ ) vines than in the Control vines (leaf blade $\mathrm{P}=1.5 \mathrm{~g} / \mathrm{kg} \mathrm{DW}$ ) in 2012. In 2013 and 2014, the 15 and $30 \% \mathrm{~N}$ vines had even higher $\mathrm{P}$ concentrations in both leaf blades and petioles (leaf blade ranging from 3.4 to $5.2 \mathrm{~g} \mathrm{P} / \mathrm{kg} \mathrm{DW}$ ) at veraison compared to the Control (leaf blade ranging from 1.7 to $1.8 \mathrm{~g} \mathrm{P} / \mathrm{kg} \mathrm{DW})$. Lower S concentrations occurred in both leaf blades and petioles at veraison in all years with 15 and $30 \% \mathrm{~N}$ vines (leaf blade $\mathrm{S}=1.4 \mathrm{~g} / \mathrm{kg}$ DW) than in the Controls (leaf blade $\mathrm{S}=1.9 \mathrm{~g} / \mathrm{kg} \mathrm{DW}$ ), even though $\mathrm{SO}_{4}-\mathrm{S}$ was supplied to all $\mathrm{N}$ treatments at the same concentration. The only other nutrient showing a consistent effect over time was boron (B), where veraison leaf blade B concentrations were greater in $15 \% \mathrm{~N}$ vines (ranging from 57

Table 1 Leaf blade and petiole nitrogen $(\mathrm{N})$ concentrations at bloom and veraison in Pinot noir grapevines grown in microplots at varying rates of $\mathrm{N}$ from 2012 to 2014. Data are means and standard errors of the mean for each factor ( $n=20$ for year, $n=12$ for $N$ supply, $n=4$ for $Y \cdot N$ supply interaction).

\begin{tabular}{|c|c|c|c|c|c|}
\hline \multirow[b]{2}{*}{ Effect } & \multirow[b]{2}{*}{ Level } & \multicolumn{2}{|c|}{ Bloom N (g N/kg DW) } & \multicolumn{2}{|c|}{ Veraison N (g N/kg DW) } \\
\hline & & Leaf blade & Petiole & Leaf blade & Petiole \\
\hline \multirow[t]{3}{*}{ Year } & 2012 & $22.3(0.5) b^{a}$ & $6.0(0.2) b$ & $17.9(0.5) b$ & $3.7(0.1) c$ \\
\hline & 2013 & $23.3(0.6) \mathrm{a}$ & $7.4(0.2) a$ & $19.1(0.6) \mathrm{a}$ & $4.6(0.1) \mathrm{a}$ \\
\hline & 2014 & $23.6(0.7) \mathrm{a}$ & $7.5(0.2) a$ & $19.6(0.7) \mathrm{a}$ & $4.2(0.1) b$ \\
\hline ANOVA $^{\text {b }}$ sig. level $(p)$ & & $<0.001$ & $<0.001$ & $<0.001$ & $<0.001$ \\
\hline \multirow[t]{5}{*}{$\mathrm{N}$ supply ${ }^{\mathrm{c}}$} & $100 \%$ & $26.6(0.4) \mathrm{a}$ & $8.2(0.3) a$ & $22.2(0.4) a$ & $4.8(0.1) \mathrm{a}$ \\
\hline & $75 \%$ & $24.9(0.3) b$ & $7.2(0.2) b$ & $21.0(0.4) b$ & $4.6(0.1) b$ \\
\hline & $50 \%$ & $23.0(0.3) c$ & $6.9(0.2) b$ & $19.0(0.3) \mathrm{c}$ & $4.2(0.1) c$ \\
\hline & $30 \%$ & $20.9(0.3) d$ & $6.4(0.2) c$ & $16.9(0.2) \mathrm{d}$ & $3.8(0.1) d$ \\
\hline & $15 \%$ & $20.1(0.3) d$ & $6.1(0.2) \mathrm{c}$ & $15.3(0.3) \mathrm{e}$ & $3.6(0.1) \mathrm{e}$ \\
\hline ANOVA sig. level $(p)$ & & $<0.001$ & $<0.001$ & $<0.001$ & $<0.001$ \\
\hline \multirow[t]{15}{*}{$\mathrm{Y} \cdot \mathrm{N}$ supply } & $2012-100 \%$ & $25.2(0.2)$ & $6.9(0.3)$ cde & $20.6(0.3) \mathrm{bcd}$ & $4.3(0.2)$ \\
\hline & $2012-75 \%$ & $24.1(0.4)$ & $6.2(0.2)$ def & $19.7(0.3) \mathrm{cd}$ & $4.1(0.1)$ \\
\hline & $2012-50 \%$ & $22.4(0.5)$ & $6.1(0.1)$ efg & $18.8(0.4) \mathrm{de}$ & $3.9(0.1)$ \\
\hline & $2012-30 \%$ & $20.4(0.5)$ & $5.4(0.1) \mathrm{fg}$ & $16.5(0.4) f$ & $3.4(0.1)$ \\
\hline & $2012-15 \%$ & $19.7(0.5)$ & $5.2(0.1) \mathrm{g}$ & $14.2(0.2) \mathrm{g}$ & $3.1(0.1)$ \\
\hline & $2013-100 \%$ & $26.4(0.4)$ & $8.5(0.2) a b$ & $22.2(0.2) a b$ & $5.1(0.1)$ \\
\hline & $2013-75 \%$ & $25.5(0.6)$ & $7.7(0.2) b c$ & $21.3(0.4) \mathrm{bc}$ & $5.0(0.1)$ \\
\hline & $2013-50 \%$ & $23.5(0.6)$ & $7.5(0.2) b c$ & $18.9(0.5) \mathrm{de}$ & $4.6(0.1)$ \\
\hline & $2013-30 \%$ & $21.2(0.5)$ & $6.8(0.2) \mathrm{cde}$ & $17.2(0.3)$ ef & $4.2(0.1)$ \\
\hline & $2013-15 \%$ & $20.2(0.3)$ & $6.5(0.1) \mathrm{de}$ & $15.7(0.4) \mathrm{fg}$ & $4.1(0.1)$ \\
\hline & $2014-100 \%$ & $28.1(0.5)$ & $9.3(0.3) a$ & $23.8(0.4) a$ & $5.0(0.1)$ \\
\hline & $2014-75 \%$ & $25.1(0.3)$ & $7.6(0.2) \mathrm{bc}$ & $21.9(0.5) a b$ & $4.7(0.1)$ \\
\hline & $2014-50 \%$ & $23.3(0.5)$ & $7.1(0.1) \mathrm{cd}$ & $19.3(0.6) \mathrm{d}$ & $4.1(0.1)$ \\
\hline & $2014-30 \%$ & $21.0(0.6)$ & $7.0(0.1) \mathrm{cde}$ & $17.0(0.4)$ ef & $3.7(0.1)$ \\
\hline & $2014-15 \%$ & $20.4(0.6)$ & $6.6(0.1) \mathrm{de}$ & $16.2(0.5) f$ & $3.6(0.1)$ \\
\hline ANOVA sig. level $(p)$ & & 0.304 & 0.031 & 0.028 & 0.136 \\
\hline
\end{tabular}

aMeans followed by the same letter within an effect do not differ based on Tukey's honest significant difference at $95 \%$ confidence. ${ }^{\mathrm{b} A N O V A}$, analysis of variance.

${ }^{\mathrm{C}} \mathrm{N}$ supply is expressed as \% of Control level of $\mathrm{N}$ supplied during fertigation events, $100 \%$ is equivalent to $7.5 \mathrm{mM} \mathrm{N}$. 
to $71 \mathrm{mg} \mathrm{B} / \mathrm{kg} \mathrm{DW}$ ) than in the Control (ranging from 40 to 50 $\mathrm{mg} \mathrm{B} / \mathrm{kg} \mathrm{DW}$ ) in all years, although petiole B concentrations did not differ in any year.

Vine vegetative growth parameters were highly responsive to $\mathrm{N}$ supply (Figure 1), and an interaction with year was significant for all growth measures, since effects became larger over time. Bloom shoot length showed no treatment differences in 2012, but by 2013, shoot length was lower in the three lowest $\mathrm{N}$ treatments compared to the Control. By 2014, shoot length in the two lowest $\mathrm{N}$ treatments had dropped even further. The $75 \% \mathrm{~N}$ vines did not differ from the Controls in any year. Bloom leaf area responded similarly to bloom shoot length. By 2014, shoot length and leaf area at bloom in both the 30 and $15 \% \mathrm{~N}$ vines was $\sim 50 \%$ lower than the Controls, and the $50 \% \mathrm{~N}$ vines were $\sim 25 \%$ lower than the Controls. At veraison, leaf area was already reduced in the three lowest $\mathrm{N}$ treatments in 2012, and by 2013 and 2014, leaf area was also lower in the $75 \% \mathrm{~N}$ vines than in the Controls. The dormant season pruning weights showed a sharper decline over time in the low $\mathrm{N}$ treatments than leaf area; however, only vines in the two lowest $\mathrm{N}$ rates differed from the Controls in 2012, while vines at the three lowest $\mathrm{N}$ rates differed in 2013 and 2014.
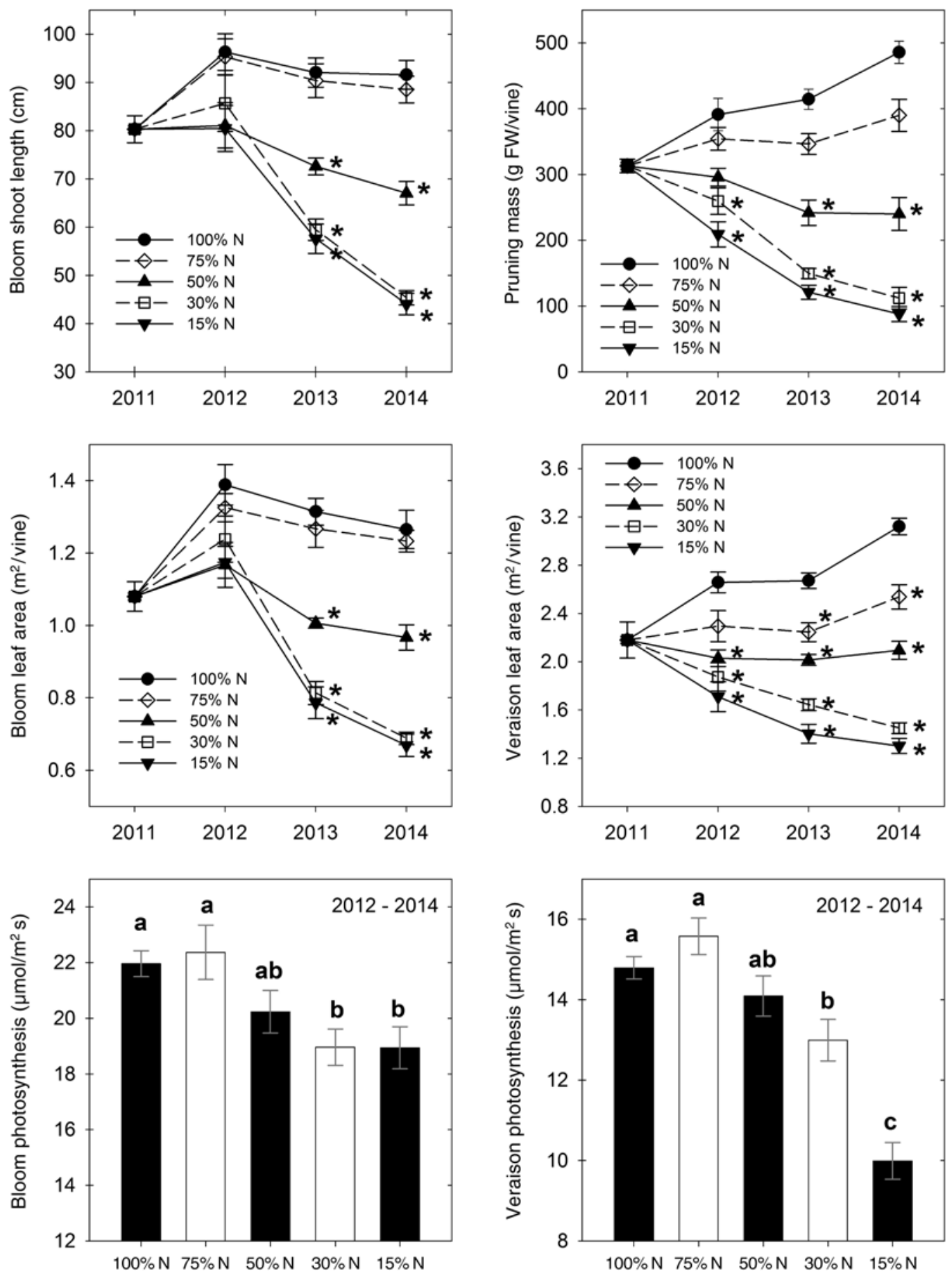

Figure 1 Effect of year and nitrogen (N) supply on vegetative parameters of Pinot noir grown in microplots from 2012 to 2014. Interactive effect of year and $\mathrm{N}$ supply (scatter charts) on bloom shoot length, bloom leaf area, pruning mass, and veraison leaf area $(n=4)$, and main effect of $\mathrm{N}$ supply (bar charts) on midday bloom and verasion single leaf photosynthesis $(n=12) . A$ * to the right of a symbol in interactive plots indicates those $\mathrm{N}$ treatments that differ from the Control $(100 \% \mathrm{~N})$ in each year based on Tukey's honest significant difference (HSD) at 95\% confidence. Data from 2011 before $\mathrm{N}$ was manipulated are shown as a reference in interactive plots. Letters above means in bar charts indicate treatment differences based on Tukey's HSD at $95 \%$ confidence. Data are means and standard error of the mean for each plot. FW, fresh weight. 
Leaf photosynthesis at midday was affected by $\mathrm{N}$ rate, but not by year, at both bloom and veraison (Figure 1). The rate of photosynthetic carbon fixation at bloom was reduced by $\sim 13 \%$ in the 30 and $15 \% \mathrm{~N}$ vines, but at veraison, photosynthetic rate in the $15 \% \mathrm{~N}$ vines was reduced even further than the $30 \% \mathrm{~N}$ vines, to $\sim 30 \%$ lower than the Controls. Measurements taken later in the day (1500 to $1600 \mathrm{hr})$ across all years showed less impact of $\mathrm{N}$ supply on photosynthesis (data not shown). For example, late day photosynthesis rates at veraison did not differ among the different $\mathrm{N}$ treatments, and only the
$30 \% \mathrm{~N}$ vines had a lower photosynthesis rate at bloom in one year (2013) than the other treatments (including the $15 \% \mathrm{~N}$ vines). Therefore, $\mathrm{N}$ status had a greater impact on single leaf photosynthesis at midday, but little impact late in the day.

Vine reproductive parameters were influenced less by $\mathrm{N}$ supply than were vegetative parameters. Fruitfulness was reduced only in the lowest $\mathrm{N}$ treatment across all years, with $15 \% \mathrm{~N}$ vines having fewer clusters per shoot than the three highest $\mathrm{N}$ rates (Figure 2). The number of individual flowers produced per inflorescence was not changed by $\mathrm{N}$, but was
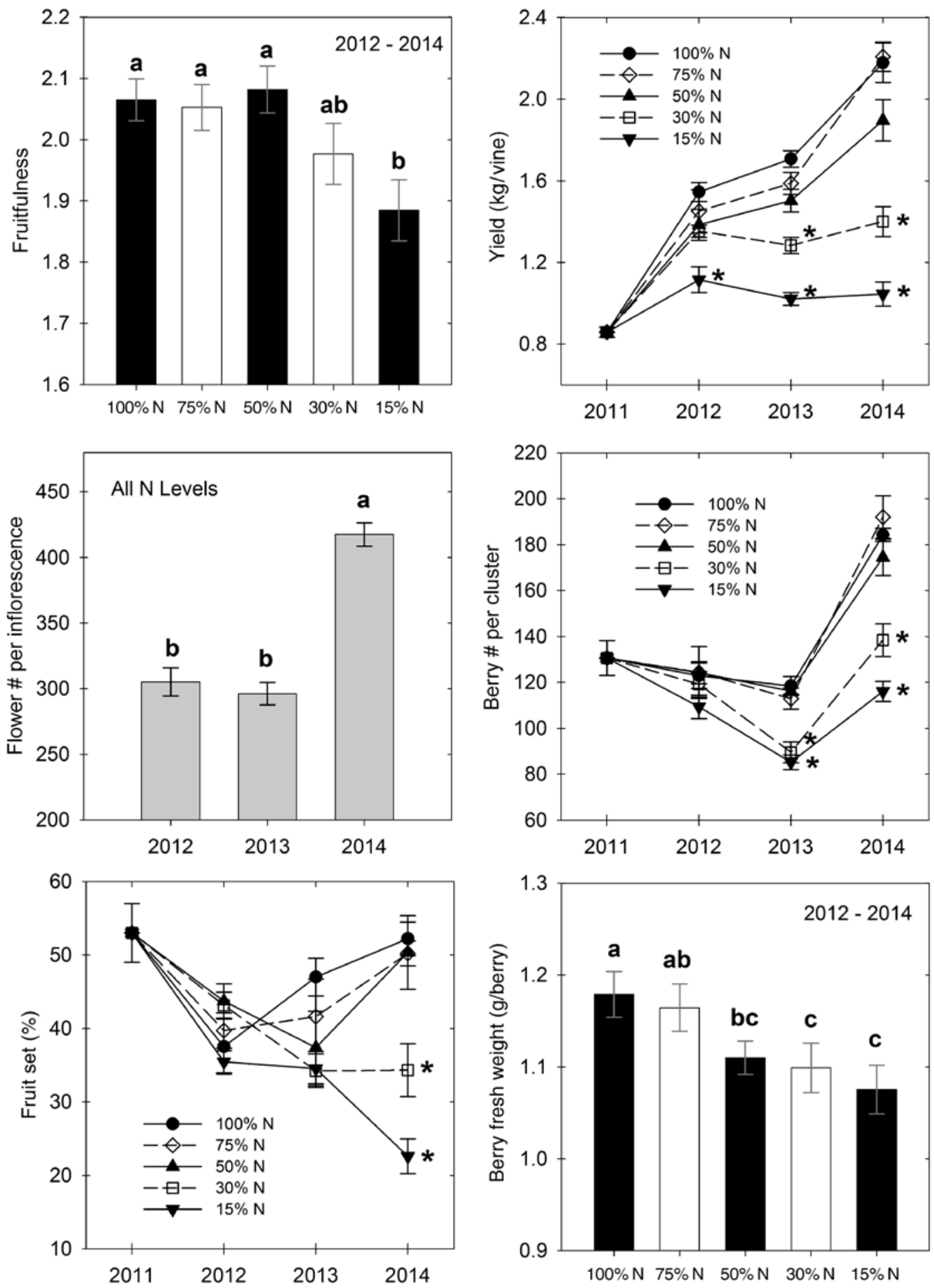

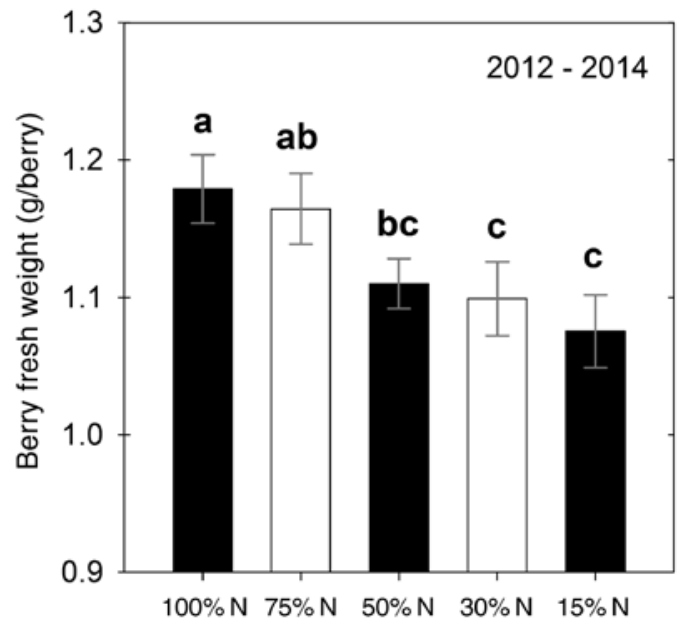

Figure 2 Effect of year and nitrogen $(\mathrm{N})$ supply on reproductive parameters of Pinot noir grown in microplots from 2012 to 2014. Interactive effect of year and $\mathrm{N}$ supply (scatter charts) on yield $(n=4)$, fruit set $(n=4)$, and berry number per cluster $(n=4)$, and main effect of $\mathrm{N}$ supply (bar charts) on fruitfulness (inflorescences per shoot) and berry fresh weight ( $\mathrm{n}$ $=12$ ), or main effect of year on flower number per inflorescence ( $\mathrm{n}$ $=20$ ). $A$ * to the right of a symbol in interactive plots indicates those $\mathrm{N}$ treatments that differ from the Control $(100 \% N)$ in each year based on Tukey's honest significant difference (HSD) at 95\% confidence. Data from 2011 before $\mathrm{N}$ was manipulated are shown as a reference in interactive plots. Letters above means in bar charts indicate treatment differences based on Tukey's HSD at $95 \%$ confidence. Data are means and standard error of the mean for each plot. 
substantially higher in 2014 than in the prior two years by $\sim 40 \%$. Flower numbers per inflorescence were again lower in 2015 in all N treatments, similar to 2012 and 2013 (data not shown), indicating that 2014 was an unusual year. The number of flowers that set fruit was only reduced by $\mathrm{N}$ in 2014, with lower fruit set in the $30 \% \mathrm{~N}$ vines and a further reduction in the $15 \% \mathrm{~N}$ vines. However, the final berry number per cluster at harvest was lower in both 2013 and 2014 in these two lowest $\mathrm{N}$ treatments, even though fruit set was only reduced in 2014. Yield was reduced in the $15 \% \mathrm{~N}$ vines in all years, while it was reduced in the 30\% N vines in 2013 and 2014.
Yield was not reduced in the 50 or $75 \% \mathrm{~N}$ vines compared to the Control in any year. The average berry weight was reduced similarly in all three of the lowest $\mathrm{N}$ treatments across years, with the $15 \% \mathrm{~N}$ treatment showing a decrease of $\sim 8 \%$ compared to the Control. All fruit was visually disease-free (no incidence of mildew or grey mold) at harvest in all years, except for four clusters in 2013 that had a few berries with grey mold (Botrytis).

Effects of $\mathrm{N}$ on must maturity indices (sugars, acids, and $\mathrm{pH}$ ) were minor and inconsistent across years (Figure 3). Soluble solids differed in one treatment each in 2013 and 2014.
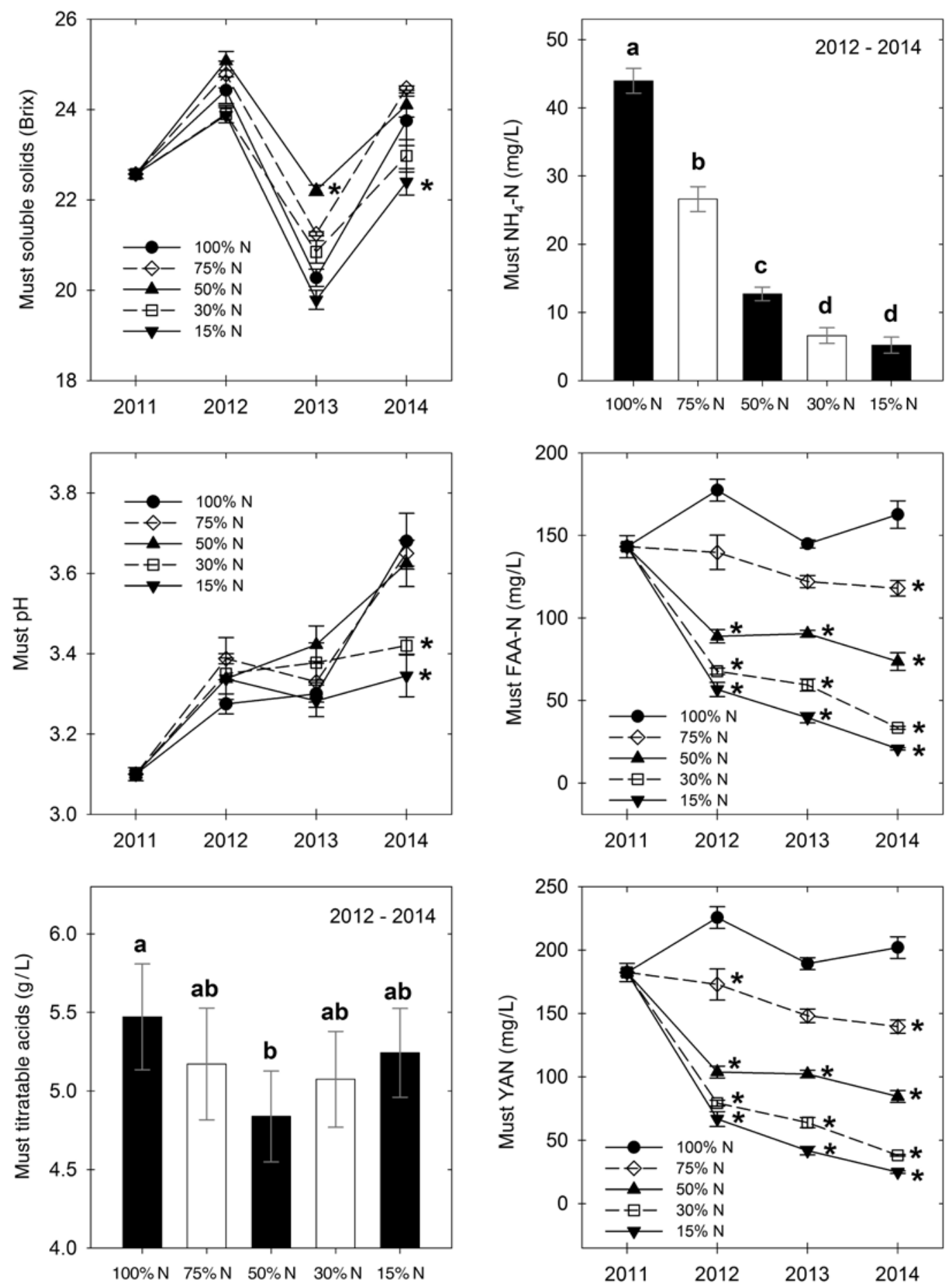
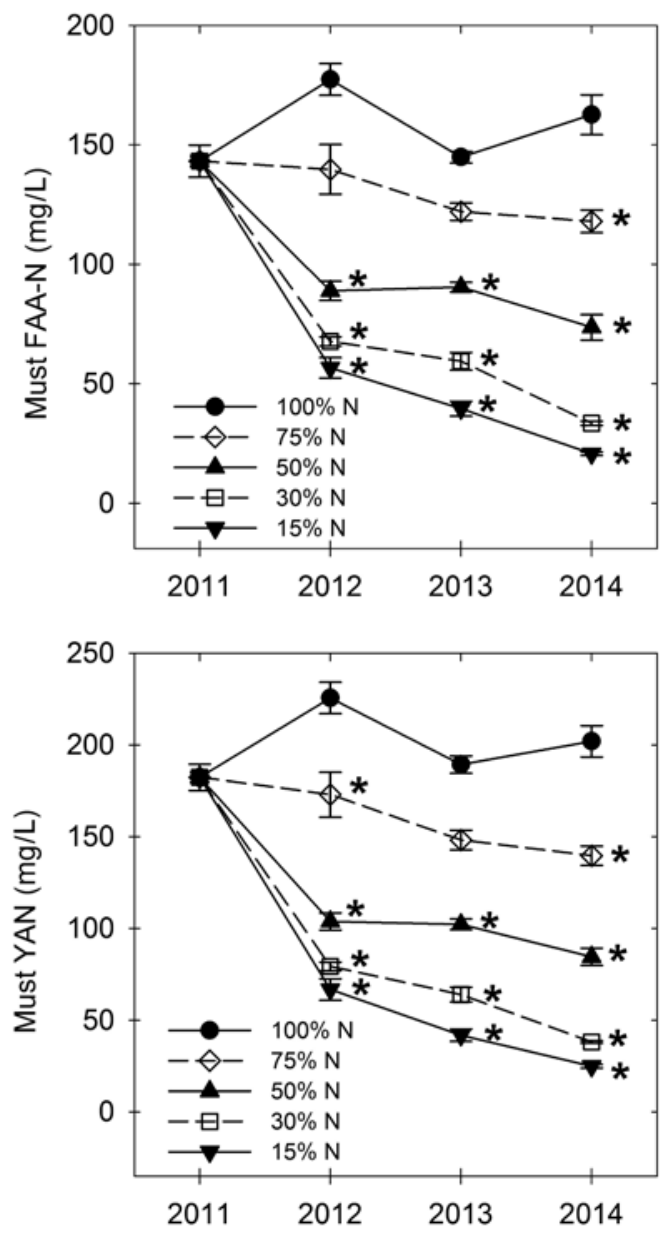

Figure 3 Effect of year and nitrogen (N) supply on must parameters of Pinot noir grown in microplots from 2012 to 2014. Interactive effect of year and $\mathrm{N}$ supply (scatter charts) on soluble solids, $\mathrm{pH}$, free amino acid-N (FAA-N), and yeast assimilable nitrogen (YAN) $(n=4)$, and main effect of $\mathrm{N}$ supply (bar charts) on ammonium- $\mathrm{N}\left(\mathrm{NH}_{4}-\mathrm{N}\right)$ and titratable acidity $(n=12) . A$ * to the right of a symbol in interactive plots indicates those $\mathrm{N}$ treatments that differ from the Control $(100 \%$ $\mathrm{N}$ ) in each year based on Tukey's honest significant difference (HSD) at $95 \%$ confidence. Data from 2011 before $\mathrm{N}$ was manipulated are shown as a reference in interactive plots. Letters above means in bar charts indicate treatment differences based on Tukey's HSD at $95 \%$ confidence. Data are means and standard error of the mean for each plot. 
The $50 \% \mathrm{~N}$ vines had higher soluble solids than all other treatments except the $75 \% \mathrm{~N}$ vines in 2013 , and the $15 \% \mathrm{~N}$ vines had lower soluble solids than the three highest $\mathrm{N}$ levels $(50$ to $100 \% \mathrm{~N})$ in 2014 . No other treatments differed from the Control vines in other years, but 2013, during which there was high rainfall prior to harvest, had lower soluble solids than 2012 and 2014. Must pH was altered by N supply only in 2014, when the two lowest $\mathrm{N}$ rates had lower $\mathrm{pH}$ that year. Must $\mathrm{pH}$ was also higher across all treatments in 2014 than in the previous years. Titratable acidity was $\sim 12 \%$ lower in the $50 \% \mathrm{~N}$ vines than in the Control vines across all years, but other $\mathrm{N}$ treatments did not differ from either of those treatments. Year also affected acids, as the 2014 musts had lower titratable acidity than the prior two years, consistent with the higher $\mathrm{pH}$ in 2014.

As expected, must $\mathrm{N}$ concentrations were strongly influenced by $\mathrm{N}$ supply. Must ammonium- $\mathrm{N}$ was reduced across all years as $\mathrm{N}$ rate declined. Both FAA-N and YAN showed nearly identical trends in response to $\mathrm{N}$ over time, as most of YAN was contributed by amino-N. Must FAA-N and YAN values were fairly consistent from 2012 to 2014 in the Control and $75 \% \mathrm{~N}$ vines, with values for YAN ranging from 190 to $230 \mathrm{mg} \mathrm{N} / \mathrm{L}$ in the Controls, and from 145 to 175 in the $75 \%$ $\mathrm{N}$ vines. YAN was lower in the $75 \% \mathrm{~N}$ vines than in the Control vines in 2012 and 2014. The three lowest $\mathrm{N}$ treatments had lower YAN than both the Control and $75 \% \mathrm{~N}$ vines in all years, and the two lowest $\mathrm{N}$ rates showed significant declines over time that were not significant for the $50 \% \mathrm{~N}$ vines. The $50 \% \mathrm{~N}$ vines had YAN concentrations of $\sim 100 \mathrm{mg} \mathrm{N} / \mathrm{L}$ across years, while the $30 \% \mathrm{~N}$ vines declined from $\sim 80 \mathrm{mg} \mathrm{N} / \mathrm{L}$ in 2012 to $\sim 40 \mathrm{mg} \mathrm{N} / \mathrm{L}$ by 2014 . The $15 \% \mathrm{~N}$ vines declined from $\sim 70 \mathrm{mg} \mathrm{N} / \mathrm{L}$ in 2012 to $\sim 25 \mathrm{mg} \mathrm{N} / \mathrm{L}$ in 2014.

The relative impact of $\mathrm{N}$ status on different vine response variables was compared by identifying the leaf blade $\mathrm{N}$ concentration at veraison that equated to a $30 \%$ reduction for each response parameter using regression (Table 2). This analysis (ranked in order of most to least affected by $\mathrm{N}$ status) revealed that vine $\mathrm{N}$ status has the greatest impact on must

Table 2 Veraison leaf blade nitrogen $(\mathrm{N})$ concentrations where key vine performance variables were reduced by $30 \%$ for Pinot noir grapevines grown in microplots at varying $\mathrm{N}$ rates from 2012 to 2014. Data were derived from regressions of each variable relative to the Control $(100 \% \mathrm{~N})$ treatment against leaf blade $\mathrm{N}$ concentrations at veraison.

\begin{tabular}{|c|c|c|c|c|}
\hline \multirow[b]{2}{*}{ Variable } & \multicolumn{4}{|c|}{$\begin{array}{l}\text { Veraison leaf blade } \mathrm{N} \text { concentration } \\
(\mathrm{g} \mathrm{N} / \mathrm{kg} \mathrm{DW})^{\mathrm{a}} \text { where vine responses } \\
\text { were reduced by } 30 \% \text { of control vines. }\end{array}$} \\
\hline & 2012 & 2013 & 2014 & All years \\
\hline Must YAN ${ }^{b}$ (mg/L) & 19.3 & 20.2 & 21.8 & 20.7 \\
\hline Pruning mass (g FW ${ }^{b}$ ) & 16.9 & 19.8 & 21.3 & 19.7 \\
\hline Veraison leaf area $\left(\mathrm{m}^{2}\right)$ & 16.4 & 18.4 & 20.0 & 18.4 \\
\hline Yield (kg) & 13.5 & 16.7 & 17.9 & 16.1 \\
\hline Bloom shoot length $(\mathrm{cm})$ & 10.4 & 17.3 & 19.1 & 16.0 \\
\hline $\begin{array}{l}\text { Veraison photosynthesis } \\
\left(\mu \mathrm{mol} / \mathrm{m}^{2} \cdot \mathrm{s}^{1}\right)\end{array}$ & 14.4 & 12.8 & 14.5 & 14.0 \\
\hline
\end{tabular}

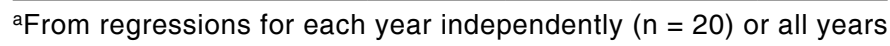
combined $(n=60)$. DW, dry weight.

bYAN, yeast assimilable nitrogen. FW, fresh weight.
YAN levels. Must YAN was reduced by $30 \%$ when leaf blade $\mathrm{N}$ was between 19 to $22 \mathrm{~g} \mathrm{~N} / \mathrm{kg}$ DW. Pruning weights were reduced by $30 \%$ at fairly similar leaf blade $\mathrm{N}$ status in 2013 and 2014 ( 20 to $21 \mathrm{~g} \mathrm{~N} / \mathrm{kg} \mathrm{DW}$ ), but the point where pruning mass values were reduced by $30 \%$ in 2012 was considerably lower (17 g N/kg DW), since $\mathrm{N}$ effects on growth were cumulative over time. While a similar difference was also true for YAN in 2012, the difference in $\mathrm{N}$ status in that year was not as great as for pruning mass, indicating that $\mathrm{N}$ status influences YAN more quickly than growth. Leaf area at veraison was the next most sensitive variable to $\mathrm{N}$ status, showing a $30 \%$ reduction when leaf blade $\mathrm{N}$ was 16 to $20 \mathrm{~g} \mathrm{~N} / \mathrm{kg}$ DW. Yield and bloom shoot length were less sensitive to $\mathrm{N}$ status, showing a $30 \%$ decline at leaf blade $\mathrm{N}$ concentrations averaged across all years of $16 \mathrm{~g} \mathrm{~N} / \mathrm{kg}$ DW. Both yield and shoot length at bloom had much lower values in 2012, owing to the cumulative impact of low $\mathrm{N}$ supply. Leaf photosynthesis was even less responsive, with $30 \%$ lower rates occurring at a leaf blade $\mathrm{N}$ status of $\sim 14 \mathrm{~g} \mathrm{~N} / \mathrm{kg}$ DW.

$\mathrm{N}$ supply and the resulting change in must YAN concentrations influenced alcoholic fermentation (Figure 4). The musts from higher $\mathrm{N}$ treatments $(100 \% \mathrm{~N}$ and $75 \% \mathrm{~N})$ completed alcoholic fermentation within four to five days in all years and did not differ, while the $50 \% \mathrm{~N}$ musts took longer and completed ferment in about seven days. Fermentations of the two lowest $\mathrm{N}$ treatments, 30 and $15 \% \mathrm{~N}$, took eight to 10 days to complete in 2012 and 2013, and even longer in 2014 (17 days for $15 \% \mathrm{~N}$ musts) (Figure 4A). However, musts reached dryness (fermentations completed) in all years, even when must YAN was as low as $25 \mathrm{mg} \mathrm{N} / \mathrm{L}(15 \% \mathrm{~N}$ musts in 2014). Data from all years from the individual replicates showed that the time needed to complete fermentation increased dramatically when must YAN was below $\sim 100 \mathrm{mg} \mathrm{N} / \mathrm{L}$ (Figure 4B). The fitted curve (exponential decay) accounted for nearly $90 \%$ of the variation in ferment time as a function of must YAN level.

\section{Discussion}

The key finding from this study is that $\mathrm{N}$ supply altered vine production variables and must chemistry to different degrees. Vegetative growth parameters of Pinot noir grafted onto 101-14 rootstock were constrained more than reproductive growth parameters as $\mathrm{N}$ status decreased. This is particularly relevant for yield and pruning mass of vines, two common parameters used by viticulturists to understand vine vegetative and reproductive balance (Jackson and Lombard 1993, Kliewer and Dokoozlian 2005). While the pruning mass and yield of vines were both reduced by low $\mathrm{N}$ with a greater impact over time, pruning mass decreased more than yield. Impacts on yield occurred at a lower vine $\mathrm{N}$ status. A greater impact of $\mathrm{N}$ supply on vegetative pruning mass than on yield was found in previous $\mathrm{N}$ trials with grapevines (Kliewer at al. 1991, Bell and Robson 1999, Schreiner et al. 2013), but others have reported similar gains, or even inconsistent gains, in both parameters as N status increased (Conradie and Saayman 1989, Conradie 2001, Pérez-Álvarez et al. 2013). The inconsistent responses to $\mathrm{N}$ in vegetative versus reproductive growth across studies may reflect different $\mathrm{N}$ thresholds for canopy 
growth versus fruit development among different cultivars of grapevines, or may reflect the impact of other environmental factors that differed across studies. The consistent finding of greater impact on pruning mass than on yield from this and a prior trial (Schreiner et al. 2013) with Pinot noir that used microplots and fertigation to carefully control vine $\mathrm{N}$ status has important implications in managing Pinot noir grapevines in western Oregon, where canopies grow vigorously and yield is restricted to relatively low levels. Both studies show that $\mathrm{N}$ reduction (or manipulation) can be used as a tool to reduce vine vegetative growth prior to impacting yield when producing low to moderate yield targets that are typical for premium Pinot noir. Based on these findings, viticulturists should be able to reduce canopy size by using means to reduce vine $\mathrm{N}$ status within a given vineyard, while maintaining the same target yields. Since lowering N status generally improves fruit composition of red cultivars (Jackson and Lombard 1993, Keller at al. 1999, Treeby et al. 2000, Hilbert et al. 2003, Schreiner et al. 2014), fruit and wine quality
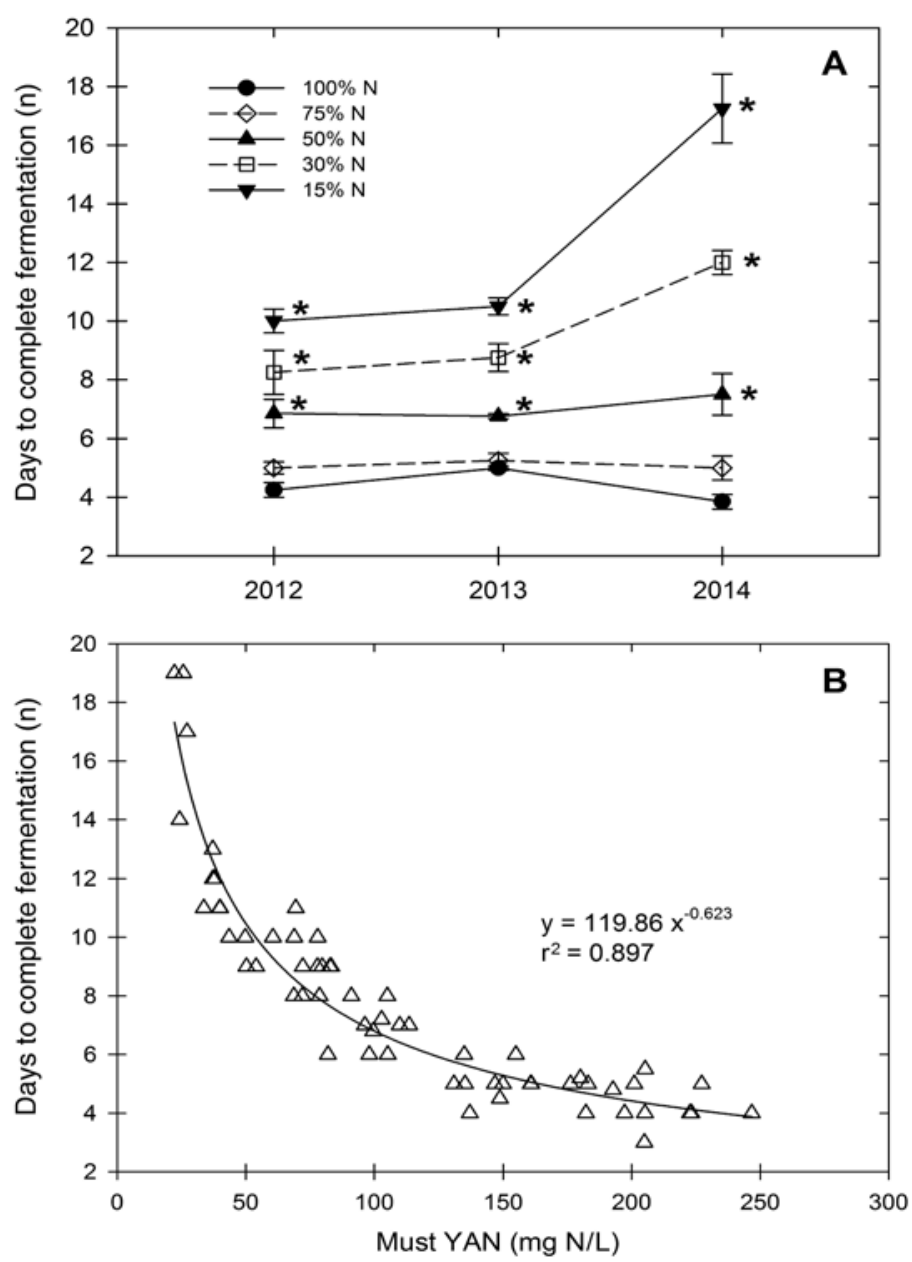

Figure 4 Effect of year and nitrogen $(\mathrm{N})$ supply on fermentation time (A) and the relationship between must yeast assimilable nitrogen (YAN) levels and fermentation time $(\mathbf{B})$ in individual wine replicates. Data in $(\mathbf{A})$ are means and standard error of the mean $(n=4)$, and data in $(B)$ are raw data points from all years and treatments. $A$ * to the right of a symbol in (A) indicates those $\mathrm{N}$ treatments that differ from the control $(100 \% \mathrm{~N})$ in each year based on Tukey's honest significant difference at $95 \%$ confidence. may also increase with lower $\mathrm{N}$ status. Our data suggest that viticulturists in the region have some room to adjust vine $\mathrm{N}$ status to reduce canopy size and possibly improve fruit composition before suffering a yield loss. Reduced $\mathrm{N}$ status could be achieved by reducing $\mathrm{N}$ inputs directly, or by other means such as increasing competitive vineyard floor vegetation or using low $\mathrm{N}$ rootstocks (Reeve et al. 2016). The caveat is that must YAN levels appear to be slightly more sensitive to low $\mathrm{N}$ status, so lower YAN levels will accompany lower vegetative growth.

For a 21 Brix grape must, a minimum $200 \mathrm{mg} \mathrm{N} / \mathrm{L}$ YAN is required to complete fermentation, with an additional 25 $\mathrm{mg} \mathrm{N} / \mathrm{L}$ for every one degree increase in Brix (Bisson and Butzke 2000). A minimum YAN of $267 \mathrm{mg} \mathrm{N} / \mathrm{L}$ was required for $S$. cerevisiae PYCC 4072 to complete alcoholic fermentation in a defined grape must-like medium (Mendes-Ferreira et al. 2004). In contrast, the data obtained here with low-N fruit indicates that YAN levels may not need to be as high as is often suggested for completion of alcoholic fermentation. In this study, fermentation rate was not significantly reduced until must YAN levels dropped below $\sim 100 \mathrm{mg} \mathrm{N} / \mathrm{L}$. Indeed, even the lowest-N vines in 2014 with must YAN levels of $25 \mathrm{mg} \mathrm{N} / \mathrm{L}$ completed ferments under experimental conditions, which was somewhat surprising given critical ranges reported in the literature. Merlot musts completed fermentation with YAN values as low as $\sim 60 \mathrm{mg} \mathrm{N} / \mathrm{L}$, although their fermentation rates for higher $\mathrm{N}$ musts were slower than found here (Stockert et al. 2013). Musts containing $\leq 100 \mathrm{mg} \mathrm{N} / \mathrm{L}$ fermented to dryness (Wang et al. 2003, Ugliano et al. 2009), while others have suggested $140 \mathrm{mg} \mathrm{N} / \mathrm{L}$ as the minimum YAN concentration required to ensure complete fermentation (Jiranek et al. 1995, Martinez-Moreno et al. 2012). Indeed, a minimum YAN of $140 \mathrm{mg} \mathrm{N} / \mathrm{L}$ is commonly used in the industry.

Determining minimum YAN requirements for fermentations is complicated because there are large differences in N use among S. cerevisiae yeast strains (Jiranek et al. 1995, Mendes-Ferreira et al. 2004). The yeast strain used in our trial with Pinot noir, S. cerevisiae RC212, is considered (by the supplier) to require a moderate to high level of YAN. However, this yeast strain was able to complete fermentation in a very low-YAN must in our study and suggests that lower YANs could still be considered even when using yeast strains with higher nutrient requirements. The method of wine fermentation employed here (small lots with a submerged cap) may be an important factor in why these musts completed fermentation at such low YANs, but we found no published work comparing small lab-scale fermentations to larger scale ferments in relation to YAN requirements. Although, Casalta et al. (2010) reported that 1-L ferments did not appreciably differ in fermentation kinetics compared to 100-L ferments for Grenache blanc and Sauvignon blanc, as long as grape solids were included with clarified musts. Greater skin contact due to the submerged cap fermentations may have resulted in increased extraction of YAN from the skins, as must YAN values were $\sim 50 \%$ of the whole berry YAN, with the majority of the remaining YAN located in the skins (Lee and 
Schreiner 2010). Stines et al. (2000) also showed that skins contributed up to $29 \%$ of total berry YAN. However, to our knowledge, no published studies examined the impact of cap management techniques (submerged versus punch-down versus pump-over) on YAN extraction and availability to yeast during fermentation, so it is unknown if the use of submerged cap fermentation impacted YAN availability from skins.

Our findings suggest that $140 \mathrm{mg} \mathrm{N} / \mathrm{L}$ may not be the critical level of YAN needed for red wines, and it is likely that Pinot noir musts can complete fermentation with significantly less YAN. Whether this is so for other red wines must be determined. Differences in amino acid composition between red winegrape varieties may impact YAN requirements. Pinot noir is a high arginine-containing grape variety while others, such as Cabernet Sauvignon, contain lower arginine and higher concentrations of proline (Spayd and AndersonBagge 1996). While proline cannot be used by $S$. cerevisiae under anaerobic conditions, arginine is a major source of primary amino acid $\mathrm{N}$ for yeast during fermentation. Amino acid composition in conjunction with overall YAN levels may better explain observed differences in fermentation rates, and factors other than YAN in lower-YAN musts may influence fermentation rates (Stockert et al. 2013). Therefore, we suggest that minimum YAN requirements may be closer to 100 $\mathrm{mg} \mathrm{N} / \mathrm{L}$ for Pinot noir and possibly other red cultivars on the basis of completing fermentation.

Aside from fermentation rate, YAN also impacts production of hydrogen sulfide $\left(\mathrm{H}_{2} \mathrm{~S}\right)$, with low YAN often cited as a primary driver of yeast-produced $\mathrm{H}_{2} \mathrm{~S}$ (Jiranek et al. 1995). However, high YAN can also result in high $\mathrm{H}_{2} \mathrm{~S}$ production, and additional factors such as vitamin content and yeast strain may have more influence on $\mathrm{H}_{2} \mathrm{~S}$ production than YAN alone (Wang et al. 2003, Ugliano et al. 2009). While the present study does not report on wine $\mathrm{H}_{2} \mathrm{~S}$ concentration, additional analysis of the wines produced from this study showed that all of the volatile $\mathrm{S}$ compounds known to impart unpleasant aromas in wines were either at lower concentrations in the low $\mathrm{N}$ wines or did not differ from the Control $(100 \% \mathrm{~N})$ wines (F. Yuan, R.P. Schreiner, J. Osborne, and M.C. Qian, unpublished data, 2017). YAN can also affect desirable yeast-derived volatile compounds such as esters and higher alcohols, which must be considered when discussing target YAN concentrations and their relationship with wine quality (Ugliano et al. 2010). Volatile aroma analysis of wines produced from this trial (F. Yuan, R.P. Schreiner, J. Osborne, and M.C. Qian, unpublished data, 2017) will provide a more comprehensive understanding of YAN targets that consider both fermentation rate and other wine quality parameters.

Data from the $50 \% \mathrm{~N}$ treatment vines in this study are most appropriate for developing tissue $\mathrm{N}$ guidelines to manage production of grafted Pinot noir vines. The $50 \% \mathrm{~N}$ vines had similar yields as the Control vines, but with smaller, more manageable canopies (an important goal for the region). Furthermore, $50 \% \mathrm{~N}$ musts with YAN values close to $100 \mathrm{mg}$ N/L fermented to dryness in an only slightly longer timeframe than the high-N musts. Leaf blade $\mathrm{N}$ status of the $50 \%$ $\mathrm{N}$ vines ranged from 22.4 to $23.5 \mathrm{~g} \mathrm{~N} / \mathrm{kg} \mathrm{DW}$ at bloom and
18.8 to $19.3 \mathrm{~g} \mathrm{~N} / \mathrm{kg} \mathrm{DW}$ at veraison across the three years of this study. Therefore, it appears that a good estimate for critical values for leaf blade $\mathrm{N}$ are 23 to $24 \mathrm{~g} \mathrm{~N} / \mathrm{kg}$ DW at bloom and $19 \mathrm{~g} \mathrm{~N} / \mathrm{kg}$ DW at veraison. These leaf blade $\mathrm{N}$ values agree with the previous values of $25 \mathrm{~g} \mathrm{~N} / \mathrm{kg}$ DW at bloom and $18 \mathrm{~g} \mathrm{~N} / \mathrm{kg} \mathrm{DW}$ at veraison determined from own-rooted Pinot noir vines (Schreiner et al. 2013). Petiole $\mathrm{N}$ values that correspond to these leaf blade values in the $50 \% \mathrm{~N}$ vines are $7.0 \mathrm{~g} \mathrm{~N} / \mathrm{kg} \mathrm{DW}$ at bloom and $4.4 \mathrm{~g} \mathrm{~N} / \mathrm{kg}$ DW at veraison. Based on the responses of the two lowest $\mathrm{N}$ rates employed here, it appears that a single-year value of $15 \mathrm{~g} \mathrm{~N} / \mathrm{kg}$ DW in leaf blades at veraison or two consecutive years with veraison leaf blade $\mathrm{N}$ below $17.5 \mathrm{~g} \mathrm{~N} / \mathrm{kg}$ DW will result in lower yield. If producers want to obtain YAN levels of at least $140 \mathrm{mg} \mathrm{N} / \mathrm{L}$ in must, then leaf blade N, based on the $75 \% \mathrm{~N}$ vines in 2013 and 2014 where this YAN level occurred, should be 25 to 26 $\mathrm{g} \mathrm{N} / \mathrm{kg}$ DW at bloom and 21 to $22 \mathrm{~g} \mathrm{~N} / \mathrm{kg}$ DW in blades at veraison. Petiole values that equate to $140 \mathrm{YAN}$ found here in those same vines were 7.6 to $7.7 \mathrm{mg} \mathrm{N} / \mathrm{kg}$ DW at bloom and 4.7 to $5.0 \mathrm{mg} \mathrm{N} / \mathrm{kg}$ DW at veraison. These guidelines for N status agree with some previous studies (Conradie 2001, Linsenmeier et al. 2008, Schreiner et al. 2013) but are slightly higher than others for winegrapes (Robinson 2005). The aforementioned leaf blade guidelines are more reliable than the petiole values, as confirmed by regression analysis of the raw plot data from this vineyard, owing to greater year-toyear variation in petioles (Schreiner and Scagel 2017).

The aforementioned $\mathrm{N}$ guidelines may not apply to all grafted Pinot noir vineyards in the region. All data from this trial were based on vines carrying one cluster per shoot, which produced fruit yields of 5600 to $7840 \mathrm{~kg} / \mathrm{ha}$ (equivalent to 2.5 to 3.5 U.S. tons per acre). A slightly higher $\mathrm{N}$ status may be required to achieve similar goals at higher crop loads. Indeed, our data support that higher $\mathrm{N}$ status may be needed to produce higher yields, since the level of leaf blade $\mathrm{N}$ at veraison that equated to a $30 \%$ yield loss in 2014 (the highest-yield year) was $17.9 \mathrm{~g} \mathrm{~N} / \mathrm{kg} \mathrm{DW}$, compared to $16.7 \mathrm{~g}$ $\mathrm{N} / \mathrm{kg}$ DW in 2013. It seems likely and logical that a higher $\mathrm{N}$ status will be needed to maintain higher yields over time. It is not yet known how much higher $\mathrm{N}$ status guidelines must be adjusted to accommodate higher yields. The yields from this trial for the $50 \% \mathrm{~N}$ and higher $\mathrm{N}$ level vines were above typical yields (2.0 U.S. tons per acre) traditionally carried in western Oregon premium Pinot noir vineyards.

Other nutrients besides $\mathrm{N}$ were above reported critical concentrations across all treatments in any year (Conradie 2001, Robinson 2005, Schreiner et al. 2013), with the possible exception of S. Tissue guidelines for $\mathrm{S}$ are not known, owing to a lack of $\mathrm{S}$ data in grapevines. However, we found $\mathrm{S}$ values at veraison in leaf blades from commercial Pinot noir vineyards that were as low as $1.0 \mathrm{~g} \mathrm{~S} / \mathrm{kg}$ DW with no apparent effects on vine health or presence of leaf deficiency symptoms (R.P. Schreiner, unpublished data, 2017). Our bloom values for $S$ were $>2.2 \mathrm{~g} \mathrm{~S} / \mathrm{kg} \mathrm{DW}$ in leaf blades across all treatments. Critical leaf blade values for $\mathrm{S}$ near harvest in other crops appears to be $\sim 1.0 \mathrm{~g} \mathrm{~S} / \mathrm{kg} \mathrm{DW}$, with higher values earlier in the season near $2.0 \mathrm{~g} \mathrm{~S} / \mathrm{kg}$ DW (Yoshida and Chaudhry 1979, 
Withers et al. 1995). We therefore suspect that the S status of our vines was in a healthy range.

The high yield in 2014 (equating to $7840 \mathrm{~kg} / \mathrm{ha}$, or 3.5 U.S. tons per acre) was due to the higher flower number per cluster that year. $\mathrm{N}$ supply had no influence on flower number here. The greater number of flowers in 2014 may be related to lower air temperatures near the time of budbreak, as observed in Cabernet Sauvignon and Merlot where a temperature at budbreak of $12^{\circ} \mathrm{C}$ resulted in more flowers per cluster than when budbreak temperatures were near $20^{\circ} \mathrm{C}$ (May 2004). The average daily air temperature in 2014 on the day of budbreak and the following five days was $9.7^{\circ} \mathrm{C}$, but the corresponding temperatures in 2012 and 2013 were $12.5^{\circ} \mathrm{C}$ and $12.1^{\circ} \mathrm{C}$, respectively. These differences were not as large as those reported previously, but vines here were grown under field conditions, where solar heating may also have influenced bud temperature (May 2004). Since N supply had no influence on flower number per inflorescence over a three year period, our data do not support recent findings that $\mathrm{N}$ status in the previous growing season influences flower number in the subsequent year (Guilpart et al. 2014), nor do they support findings from a vineyard floor trial where lower flower number was related to lower $\mathrm{N}$ status of vines (Reeve et al. 2016). Differences among these studies and our findings may be due to other factors, including vine age and weather conditions, that may interact with $\mathrm{N}$ status in influencing flower numbers per inflorescence.

In a prior $\mathrm{N}$ trial on own-rooted Pinot noir (Schreiner et al. 2013), we suggested that leaf $\mathrm{N}$ status guidelines should not be based on single-leaf photosynthesis rates, because this measure appeared to be related to crop level and source:sink responses to low $\mathrm{N}$ instead of direct $\mathrm{N}$ limitation on the photosynthetic machinery (Chen and Cheng 2003, Prieto et al. 2012). That interpretation was based on the fact that leaf blade $\mathrm{N}$ concentrations in the lowest- $\mathrm{N}$ vines in that study were the same in two years (14 to $15 \mathrm{~g} \mathrm{~N} / \mathrm{kg} \mathrm{DW}$ ), but photosynthesis at veraison was reduced only in the second year, when there was a simultaneous reduction in fruit yield. Photosynthesis was more consistently reduced by low $\mathrm{N}$ status here in grafted vines, where veraison photosynthesis was reduced in the two lowest $\mathrm{N}$ rates as a main effect across all years. However, leaf blade $\mathrm{N}$ values in those vines showing lower rates of photosynthesis (15 to $17 \mathrm{~g} \mathrm{~N} / \mathrm{kg} \mathrm{DW}$ ) were higher than the prior values. Yield was also more consistently reduced here than in the previous trial with own-rooted Pinot noir (Schreiner et al. 2013). In addition, the point where photosynthesis was reduced by $30 \%$ occurred at a much lower $\mathrm{N}$ concentration in leaf blades than the $\mathrm{N}$ status at which yield was reduced by $30 \%$ (Table 2). Results from this trial with grafted vines support our original interpretation that single-leaf photosynthesis measures are not a good response variable upon which to base leaf $\mathrm{N}$ guidelines.

Interestingly, rates of photosynthesis in low-N vines (15 and $30 \% \mathrm{~N}$ ) no longer differed from the Control vines when leaves were measured late in the day at veraison. The reason for this is not clear, although it is possible that vines with more $\mathrm{N}$ became sink-limited late in the day. Higher-N vines had greater rates of leaf photosynthesis at midday and greater overall leaf area that may have saturated the supply of fixed carbon needed by developing fruit clusters, while the low-N vines did not saturate the carbon supply needed by clusters by late afternoon, since they had lower rates of gas exchange earlier in the day and fewer leaves. Alternatively, the higher$\mathrm{N}$ vines may have had similar rates of gas exchange per leaf late in the day as the low- $\mathrm{N}$ vines because all vines were beginning to experience similar degrees of water limitation. Irrigation inputs were managed in this trial to obtain similar soil moisture levels late in the day, so this latter explanation may better explain why high- and low-N vines had similar photosynthesis rates late in the day. Regardless of the underlying reason for these differential effects of low $\mathrm{N}$ status on leaf level photosynthesis at different times of the day, the higher-N vines clearly fixed more carbon per vine to support the higher fruit yields.

If low-N Pinot noir fruit results in desirable phenolic and aromatic composition and improves overall wine quality or has similar quality to high-N fruit, then reducing $\mathrm{N}$ status and vine canopy size would be strongly encouraged to reduce inputs and the environmental footprint of vineyards. Often high$\mathrm{N}$ status vineyards are managed to deal with excessive canopy growth by adopting expensive canopy management practices such as repeated hedging. Reducing vine $\mathrm{N}$ status would help avoid these extra management costs. Furthermore, repeated hedging of high-N vines resulted in poor color development in Pinot noir (Keller et al. 1999). Reducing $\mathrm{N}$ fertilizer to achieve lower vine $\mathrm{N}$ status will reduce potential nutrient leaching to groundwater. Growing smaller canopies in vigorous vineyards by adopting practices to reduce vine $\mathrm{N}$ status will also result in lower water requirements per unit land area. These production changes can provide significant environmental benefits, but are difficult to value economically. Reducing vineyard water use and the potential for nutrient leaching to groundwater or watersheds should improve both the quantity of water available for other uses, including late-summer stream flows to protect aquatic habitat (Kaufmann and Hughes 2006), and the quality of that water (Carpenter et al. 1998). These goals are important components of vineyard sustainability programs that vineyards and wineries can utilize to gain market share for their products (Schäufele and Hamm 2017).

$\mathrm{N}$ management will be more challenging to fine-tune in non-irrigated vineyards, but some practices, including the use of competitive cover crops, can also reduce vine $\mathrm{N}$ status and canopy size with less impact on yield (Reeve et al. 2016). Ongoing research is addressing whether or not $\mathrm{N}$ fertilization in low-N vineyards to boost native fruit YAN produces better wines, or whether maintaining low vine $\mathrm{N}$ status, with or without winery YAN additions, produces better wines.

\section{Conclusions}

Lowering vine $\mathrm{N}$ status reduced vegetative growth more than reproductive growth of grafted Pinot noir, indicating that growers can reduce $\mathrm{N}$ supply to limit vigor before suffering a yield loss at the current yield targets for premium wine production. However, must YAN appears to be more sensitive to 
$\mathrm{N}$ status than vegetative growth, so lower YAN values can be expected when N limitation is used to reduce vigor. Further research should address whether the benefits to fruit composition of reduced $\mathrm{N}$ status in red wine cultivars outweighs the negative consequence of lower must YAN. Results based on fermentation rates suggest that $\sim 100 \mathrm{mg} \mathrm{N} / \mathrm{L}$ might be a better target for minimum YAN requirements of Pinot noir than the $140 \mathrm{mg} \mathrm{N} / \mathrm{L}$ suggested by others. The results from this study indicate that leaf blade $\mathrm{N}$ concentrations of 23 to $24 \mathrm{~g}$ $\mathrm{N} / \mathrm{kg} \mathrm{DW}$ at bloom and of $19 \mathrm{~g} \mathrm{~N} / \mathrm{kg}$ DW at veraison allow grafted Pinot noir vines to maintain yield, reduce vigor, and obtain YAN values of $\sim 100 \mathrm{mg} \mathrm{N} / \mathrm{L}$. Corresponding petiole $\mathrm{N}$ concentrations are $7.0 \mathrm{~g} \mathrm{~N} / \mathrm{kg}$ DW at bloom and $4.4 \mathrm{~g} \mathrm{~N} /$ $\mathrm{kg}$ DW at veraison. If producers wish to target YAN values of $140 \mathrm{mg} \mathrm{N} / \mathrm{L}$, then leaf blade $\mathrm{N}$ values should be 25 to 26 $\mathrm{g} \mathrm{N} / \mathrm{kg}$ DW at bloom and 21 to $22 \mathrm{~g} \mathrm{~N} / \mathrm{kg}$ DW at veraison at current yield targets.

\section{Literature Cited}

Bell S and Robson A. 1999. Effect of nitrogen fertilization on growth, canopy density, and yield of Vitis vinifera L. cv. Cabernet Sauvignon. Am J Enol Vitic 50:351-358.

Bell S and Henschke PA. 2005. Implication of nitrogen nutrition for grapes, fermentation and wine. Aust J Grape Wine Res 11:242-295.

Bisson LF and Butzke CE. 2000. Diagnosis and rectification of stuck and sluggish fermentations. Am J Enol Vitic 51:168-177.

Carpenter SR, Caraco NF, Correll DL, Howarth RW, Sharpley AN and Smith VH. 1998. Nonpoint pollution of surface waters with phosphorus and nitrogen. Ecol Appl 8:559-568.

Casalta E, Aguera E, Picou C, Rodriguez-Bencomo JJ, Salmon JM and Sablayrolles JM. 2010. A comparison of laboratory and pilotscale fermentations in winemaking conditions. Appl Microbiol Biotechnol 87:1665-1673.

Chen LS and Cheng L. 2003. Carbon assimilation and carbohydrate metabolism of 'Concord' grape (Vitis labrusca L.) leaves in response to nitrogen supply. J Amer Soc Hort Sci 128:754-760

Christensen LP, Bianchi ML, Peacock WL and Hirschfelt DJ. 1994. Effect of nitrogen fertilizer timing and rate on inorganic nitrogen status, fruit composition, and yield of grapevines. Am J Enol Vitic 45:377-387

Conradie WJ. 2001. Timing of nitrogen fertilisation and the effect of poultry manure on the performance of grapevines on sandy soil. I. Soil analysis, grape yield and vegetative growth. S Afr J Enol Vitic 22:53-59.

Conradie WJ and Saayman D. 1989. Effects of long-term nitrogen, phosphorus, and potassium fertilization on Chenin blanc vines. I. Nutrient demand and vine performance. Am J Enol Vitic 40:85-90.

Delgado R, Martín P, del Álamo M and González M. 2004. Changes in the phenolic composition of grape berries during ripening in relation to vineyard nitrogen and potassium fertilization rates. J Sci Food Agric 84:623-630.

Dukes BC and Butzke CE. 1998. Rapid determination of primary amino acids in grape juice using an $o$-phthaldialdehyde/ $\mathrm{N}$-acetylL-cysteine spectrophotometric assay. Am J Enol Vitic 49:125-134.

Guilpart N, Metay A and Gary C. 2014. Grapevine bud fertility and number of berries per bunch are determined by water and nitrogen stress around flowering in the previous year. Eur J Agron 54:9-20.

Hilbert G, Soyer JP, Molot C, Giraudon J, Milin S and Gaudillere JP. 2003. Effects of nitrogen supply on must quality and anthocyanin accumulation in berries of cv. Merlot. Vitis 42:69-76.
Hoagland DR and Arnon DI. 1950. The water-culture method for growing plants without soil. California AES Circular 347:1-32.

Jackson DI and Lombard PB. 1993. Environmental and management practices affecting grape composition and wine quality-A review. Am J Enol Vitic 44:409-430.

Jiranek V, Langridge P and Henschke PA. 1995. Regulation of hydrogen sulfide liberation in wine-producing Saccharomyces cerevisiae strains by assimilable nitrogen. Appl Environ Microbiol 61:461-467.

Jones JB and Case VW. 1990. Sampling, handling, and analyzing plant tissue samples. In Soil Testing and Plant Analysis. 3rd ed. Westerman RL (ed.), pp. 389-427. Soil Science Society of America, Madison, WI.

Kaufmann PR and Hughes RM. 2006. Geomorphic and anthropogenic influences on fish and amphibians in Pacific Northwest coastal streams. In Landscape Influences on Stream Habitat and Biological Assemblages. Symposium 48. Hughes RM et al. (eds.), pp. 429-455. American Fisheries Society, Bethesda, Maryland.

Keller M, Pool RM and Henick-Kling T. 1999. Excessive nitrogen supply and shoot trimming can impair colour development in Pinot noir grapes and wine. Aust J Grape Wine Res 5:45-55.

Kliewer WM and Dokoozlian NK. 2005. Leaf area/crop weight ratios of grapevines: Influence on fruit composition and wine quality. Am J Enol Vitic 56:170-181.

Kliewer WM, Bogdanoff C and Benz M. 1991. Reponses of Thompson Seedless grapevines trained to single and divided canopy trellis systems to nitrogen fertilization. In Proceedings of the International Symposium on Nitrogen in Grapes and Wine. Rantz JM (ed.), pp. 282-289. American Society for Enology and Viticulture, Davis, CA.

Lee J and Schreiner RP. 2010. Free amino acid profiles from 'Pinot noir' grapes are influenced by vine N-status and sample preparation method. Food Chem 119:484-489.

Linsenmeier AW, Loos U and Löhnertz O. 2008. Must composition and nitrogen uptake in a long-term trial as affected by timing of nitrogen fertilization in a cool-climate Riesling vineyard. Am J Enol Vitic 59:255-264.

Martínez-Moreno R, Morales P, Gonzalez R, Mas A and Beltran G. 2012. Biomass production and alcoholic fermentation performance of Saccharomyces cerevisiae as a function of nitrogen source. FEMS Yeast Res 12:477-485.

May P. 2004. Flowering and Fruitset in Grapevines. Lythrum Press, Adelaide, SA, Australia.

Mendes-Ferreira A, Mendes-Faia A and Leão C. 2004. Growth and fermentation patterns of Saccharomyces cerevisiae under different ammonium concentrations and its implications in winemaking industry. J Appl Microbiol 97:540-545.

Pérez-Álvarez EP, Martínez-Vidaurre JM, Martín I, García-Escudero E and Peregrina F. 2013. Relationships among soil nitrate nitrogen and nitrogen nutritional status, yield components, and must quality in semi-arid vineyards from Rioja AOC, Spain. Commun Soil Sci Plan 44:232-242.

Prieto JA, Louarn G, Perez Peña J, Ojeda H, Simonneau T and Lebon E. 2012. A leaf gas exchange model that accounts for intra-canopy variability by considering leaf nitrogen content and local acclimation to radiation in grapevine (Vitis vinifera L.). Plant Cell Environ 35:1313-1328.

Reeve AL, Skinkis PA, Vance AJ, Lee J and Tarara JM. 2016. Vineyard floor management influences 'Pinot noir' vine growth and productivity more than cluster thinning. HortSci 51:1233-1244.

Robinson JB. 2005. Critical plant tissue values and application of nutritional standards for practical use in vineyards. In Proceedings of the Soil Environment and Vine Mineral Nutrition Symposium. Christensen LP and Smart DR (eds.), pp. 61-68. American Society for Enology and Viticulture, Davis, CA. 
Roubelakis-Angelakis KA and Kliewer WM. 1992. Nitrogen metabolism in grapevines. Hort Rev 14:407-452.

Sampaio TL, Kennedy JA and Vasconcelos MC. 2007. Use of microscale fermentations in grape and wine research. Am J Enol Vitic 58:534-539.

Schäufele I and Hamm U. 2017. Consumers' perceptions, preferences and willingness-to-pay for wine with sustainability characteristics: A review. J Clean Prod 147:379-94.

Schreiner RP and Scagel CF. 2017. Leaf blade versus petiole nutrient tests as predictors of nitrogen, phosphorus, and potassium status of 'Pinot noir' grapevines. HortSci 52:174-184.

Schreiner RP, Pinkerton JN and Zasada IA. 2012. Delayed response to ring nematode (Mesocriconema xenoplax) feeding on grape roots linked to vine carbohydrate reserves and nematode feeding pressure. Soil Biol Biochem 45:89-97.

Schreiner RP, Lee J and Skinkis PA. 2013. N, P, and K supply to Pinot noir grapevines: Impact on vine nutrient status, growth, physiology and yield. Am J Enol Vitic 64:26-38.

Schreiner RP, Scagel CF and Lee J. 2014. N, P, and K supply to Pinot noir grapevines: Impact on berry phenolics and free amino acids. Am J Enol Vitic 65:43-49.

Spayd SE and Andersen-Bagge J. 1996. Free amino acid composition of grape juice from 12 Vitis vinifera cultivars in Washington. Am J Enol Vitic 47:389-402.

Stines AP, Grubb J, Gockowiak H, Henschke PA, Hoj PB and van Heeswijck R. 2000. Proline and arginine accumulation in developing berries of Vitis vinifera L. in Australian vineyards: Influence of vine cultivar, berry maturity and tissue type. Aust J Grape Wine Res 6:150-158.
Stockert CM, Bisson LF, Adams DO and Smart DR. 2013. Nitrogen status and fermentation dynamics for Merlot on two rootstocks. Am J Enol Vitic 64:195-202.

Treeby MT, Holzapfel BP, Pickering GJ and Friedrich CJ. 2000. Vineyard nitrogen supply and Shiraz grape and wine quality. Acta Hortic 512:77-92.

Ugliano M, Fredrizzi B, Siebert T, Travis B, Magno F, Versini G and Henschke PA. 2009. Effect of nitrogen supplementation and Saccharomyces species on hydrogen sulfide and other volatile sulfur compounds in Shiraz fermentation and wine. J Agric Food Chem 57:4948-4955.

Ugliano M, Travis B, Francis IL and Henschke PA. 2010. Volatile composition and sensory properties of Shiraz wines as affected by nitrogen supplementation and yeast species: Rationalizing nitrogen modulation of wine aroma. J Agric Food Chem 58:12417-12425.

Wang XD, Bohlscheid JC and Edwards CG. 2003. Fermentative activity and production of volatile compounds by Saccharomyces grown in synthetic grape juice media deficient in assimilable nitrogen and/ or pantothenic acid. J Appl Microbiol 94:349-359.

Wheeler SJ and Pickering GJ. 2003. Optimizing grape quality through soil management practices. J Food Agric Environ 1:190-197.

Withers PJA, Tytherleigh ARJ and O'Donnell FM. 1995. Effect of sulphur fertilizers on the grain yield and sulphur content of cereals. J Agric Sci 125:317-324.

Yoshida S and Chaudhry MR. 1979. Sulfur nutrition of rice. Soil Sci Plant Nutr 25:121-134. 